http://dx.doi.org/10.4314/jae.v19i2.10

\title{
Changes in the Intra-household Roles in Agriculture among Tiv Farming households in Nigeria
}

Ivande P.D.

Department of Home Science and Management, University of Agriculture Makurdi, Benue state, Nigeria

Email: ivandepd@yahoo.com

\section{Igbokwe E. M.}

Department of Agricultural Extension

Faculty of Agriculture, University Nigeria Nsukka, Enugu state, Nigeria

Email: emigbo@yahoo.com

\section{Olaolu M.O.}

Department of Agricultural Extension

Faculty of Agriculture, University Nigeria Nsukka, Enugu state, Nigeria

Email: michealolaolu@yahoo.com*

Phone: +2348065489702

\begin{abstract}
This study assessed the changes in the household roles in agriculture among the Tiv farmers during the colonial and post-colonial period. Data were collected with interview schedule that was administered to 315 household heads who are aged 50years and above. The analytical tools used included descriptive statistics such as means with percentages and the student's t-test. The findings reveals remarkable changes in the intra-household roles as men were more involved in the application of fertilizer (433\% change) and product marketing (311\% change) which were formerly women roles. The test on changes in the social organisation and farmers' capital in agriculture shows a significant change $(P<0.05)$ in communal cooperation between the colonial and post-colonial periods. Due to the fact that men are now also involved in the household activities which had earlier been known as female roles; it is recommended that extension agents should target both male and female clientele on technologies that involved their household management and household roles.
\end{abstract}

Key words: Intra-household roles in agriculture, Agriculture in colonial and post-colonial era in Tiv

\section{Introduction}

Change is a constant phenomenon in life and it takes place in physical, biological, and social universe. It calls for interest of the sociologists when it takes place within the socio-cultural universe where the questions of how, why 
and in what specific ways human societies change is the main concern (Igbo, 2003 in Ivande 2014). Social change refers to the alterations in the patterns of culture, social structure and social behavior overtime. It is the modifications that occur within social institutions, social attitudes, beliefs, values and patterns of relationship and behaviors (Igbo and Anugwom 2001 in Ivande 2014). The changes may assume different forms like modifications in human altitudes, behavior patterns as a result of education; alteration in social conditions. This could be as a result of changes in the policies of a social organization; introduction of reforms in the major laws and functional system of a society; and alteration in the material culture (arts and artifacts of the cultures).

At the advent of western science and technology with the craze for modernization that identifies tradition as the greatest barrier to development, especially economic development, (Macionis and Plummer, 2005). In spite of the discoveries that smallholder farmers' agricultural innovation practices were crucial to agricultural development, no serious efforts were made towards the development of their agricultural innovation practices during the colonial period in Nigeria (Forrest, 1985 in Ivande 2014). Rather, practices, innovations and technologies that were contrary to the agricultural organizations of the smallholder communities were introduced during the period. This was, in spite of the recognition that many of the farming practices of smallholder farmers, which were regarded as "primitive" and "misguided" were valid knowledge and skills acquired in the course of the people's age-old interaction with their environment (Richard,1985). Despite this, agricultural development policies of most developing countries, including Nigeria, have largely been influenced by their colonial pasts during which the colonialists introduced and hoisted upon their subjects, farming systems that ran contrary to the traditional farming practices of the colonized people. They furthermore promoted an exportoriented economy with greater stress on the production of crops and livestock that could benefit their economy back home without bothering whether their production was compatible with the local people's needs (Jibowo, 2005). This influence has created an indelible mark on the agricultural operation of the colonized people to the extent that even at their independence their traditional practices had to be improvised or refined or renamed to attract use or acceptance.

By post independence period (that is after 1960), a number of factors were also seen to affected agriculture to warrant a re-think. This gave rise to the decision to intervene in the organization of its performance to increase yields especially food crops yields. This led to inability of agricultural sector to fulfill its traditional roles, among which was supply of adequate food to the teaming population, especially in urban cities (Nworgu, 2006).

Prior to external contacts and intervention programmes/projects, the agricultural performance of the pre colonial Tiv people found mostly in the States of Benue, Taraba and Nasarawa, indicated that the activities that led to production were part of the duties that formed complex network of rights and 
obligations which were the kinship, family and sometimes religious and political structures (Bohannan and Bohannan, 1968). The pre colonial Tiv practiced shifting agricultural system that led to specific type of migration that allowed the Tiv to leave an entire farmland and settlement site for a new site with virgin land. Shifting cultivation is synonymous with land rotation, a discontinuous and extensive form of farming whereby cleared and cultivated fields on which crops had been rotated are again vacated to new field and left fallow over a long period for them to recoup their fertility before they are again returned to in future for cultivation and another crop rotation cycle. Tools used for cultivation were the short wooden hoe, the matchet and digging sticks. Crops cultivated by the Tiv included beans (alev), cocoyam, millet (amine) and yellow yam (anumbe). Livestock reared were shorthorned cattle and poultry (Akiga, 1939 in Ivande 2014).

Despite the social and technological organization of agriculture by the Tiv that distinguished them as committed farmers who were trusted to be able to provide food for their household and the entire nation. Contacts with colonialism, and post independence intervention programmes caused change in ideas, values, roles, social habits and the organization of the society that may have had influence on agricultural performance. The contacts introduced different skills, innovations, techniques, habits, management practices, and technologies which the Tiv farmers were exposed to and persuaded to use. These changes caused were also in the roles played by various household members. This has resulted in the quest to assess the changes that have occurred in the intra-household roles in agriculture among Tiv farming households

\section{Purpose of the study}

The broad propose of this study was to assess changes in the intra-household roles in agriculture among Tiv farming households, specifically the study sought to:

1. identify changes in farm labour and capital roles among Tiv farming households;

2. ascertain changes in intra-household decision on agricultural operation among Tiv farming households; and

3. assess the changes in the social organisation in agriculture among Tiv farming households.

\section{Methodology}

The study was carried out among the Tiv in Benue, Nasarawa, and Taraba States, Nigeria. The population of the study comprises all the Tiv farm families in Benue, Taraba and Nasarawa States. A multi-stage sampling procedure was 
employed to select farm families. Two agricultural zones predominantly populated by the Tiv, namely, zones A and B Benue and one agricultural zone each in Nasarawa and Taraba States where Tiv people are predominantly populated were purposively selected. Three blocks from zone A were sampled, while two blocks from zone B in Benue State and one block each from southern zones of Nasarawa and Taraba states were purposively selected giving a total of seven blocks. Three cells/villages were purposively selected from each block giving a total of 21 cells/villages. From the list of farm families from each of the cells/villages, 15 farm families of 50years and above were purposively selected giving a sample size of 315 farm families. This selection was to ensure that all the heads of farm families who were interviewed were not younger than 50yrs and had many years of farming experience enough to enable the extrapolation of agricultural systems of the colonial Tiv.

Data for the study were collected through the use of structured interview schedule and Focus group discussion (FGD). The interview schedule was divided into different sections on the basis of the objectives.

To ascertain the socio-cultural practices, inter and intra-household labour roles and social organization of labour and capital, respondents were asked to indicate how labour is shared among household members and organised among neighbours in the community and who decides on agricultural operations. The intra-household labour roles were measured by asking the respondents to indicate agricultural activities performed by different household members (men, women, and children) in the different periods. Inter household social organization of labour and capital factors in agriculture in the colonial and post-colonial periods were measured by asking the respondents to indicate the frequency of use of different sources of labour, and capital for agricultural production on a 3 point rating scale of: Very often $(\mathrm{VO}=3)$, Often $(\mathrm{OT}=2)$, Seldom $(S D=1)$. The weighted values were added and divided by the 3 to derive a mean value of 2 for decision. Any source with a mean score of 2 and greater than 2 was regarded as very often used any while mean scores less than 2 was regarded as seldom used.

The intra-household decisions on agricultural operations was measured by asking the respondents to indicate who took decision on the agricultural activities of the households (women, children, men) in colonial and postcolonial periods from the list of possible options: what and who informs their decisions about the type of crops/ livestock to produce and sell, who does the selling and keeps the proceeds, how the proceeds from sales are utilized among others.

To ascertain the perception of the people about social organisation and sourcing of capital practices in relation to agriculture, the respondents were asked to indicate the extent to which they agree or disagree with possible social organisation and capital practices in relation to agriculture on a five point rating scores of : very strongly agree $(\mathrm{VSA})=4$, strongly agree $(\mathrm{SA})=3$, undecided $(U D)=2$, disagree $(D A)=1$, strongly disagree $(S D A)=0$. The weighted values 
were added and divided by 5 to derive a mean value of 2 for decision. Any practice with a mean score of 2 and greater than 2 was very strongly agreed with, and any with mean value less than 2 was disagreed with. Data were analyzed with the use of percentage, percentage change, mean statistic and ttest at 0.05 level of significance.

\section{Results and Discussion}

\section{Organization of labour and capital in agriculture among the Tiv}

\section{Labour}

Data in Table 1 show the result of labour and capital were organized for agriculture in colonial and post-colonial periods. Specifically, in the colonial period, the respondents revealed that labour was very often organized using the exchange system (ihumbe) $(\mathrm{M}=2.64)$, communal cooperation (tom lohon) $(\mathrm{M}=2.50)$ and family labour $(\mathrm{M}=2.22)$. However, in the post-colonial period, agricultural labour was very often organized using hired labour $(M=2.46)$ and both family and hired labour system $(M=2.40)$. The labour role showed a significant difference in the means of communal cooperation role $(t=-16.69$, $\mathrm{P}<0.05)$, exchange labour $(\mathrm{t}=12.71 \mathrm{P}<0.05)$ and Hired labour $(\mathrm{t}=-2.96, \mathrm{P}<0.05)$ between the colonial period and post-colonial.

Changes observed were that traditional organization of labour system in the study area which were exchange system (ihumbe), communal cooperation (tom lohon) and family labour were replaced by hired labour and a combination of hired labour and family labour in the post-colonial period. The fact that this traditional organization of labour system was replaced could be attributed to the commercialization of labour for money (cash) due to the effect of the policy of taxation, marriage by cash dowry and other social endeavors which were hitherto achieved through other systems but now could only be achieved through the payment of the money (cash) as the only means of exchange. This corroborates the observation of Idyorough (2002) that during the colonial period, to coerce the farmers to produce more cash crops, the prices of cash crops were deliberately kept low. This was to make it difficult for the farmers to meet their tax demand and have enough surpluses to marry through only farming proceeds, hence forcing the farmers to commercialize their labour to augment their cash position.

\section{Capital}

Also in Table 1, capital for agriculture was very often organized using the sources of reinvesting proceeds from sale of previous harvest into agriculture $(M=2.23)$ and donations from well-wishers $(M=2.04)$ in the colonial period. By the post-colonial period, reinvestment of proceeds from sale of previous harvest $(M=2.45)$, loan from local ban (bank) $(M=2.31)$ and donations from wellwishers/ friends were the major sources of capital for agricultural operation. Here only donations from well-wishers did not shows any significant difference in the mean scores of the colonial and post-colonial periods at $P \leq 0.05$. 
The fact that these sources of capital were used very often than commercial bank loans or other credit loan schemes may be due to the fact that proceeds from sale of agricultural produce are seasonal. While loan repayment from commercial bank/ credit schemes require periodic payment irrespective of the season and also high interest rate are charged by the banks compared to the local bam (bank). Thus, the farmers may have preferred their local organization of capital for agricultural operation even in the post-colonial period when these banks and schemes were made available to the farmers.

The FGD (2012) revealed that when loans are collected from individual wellwishers or local ban, they may be paid with the physical proceeds from the harvest other than insisting on the payment of cash which the commercial banks/ loan schemes require. The implication of this finding is that farmers in the study area may not approach commercial banks or even soft loan schemes because of fear that they will not be able to pay when appropriate. Thus, for farmers in the study area to be able to participate fully in government guaranteed schemes, subsidized credit schemes or soft loans, repayment condition should be made conducive for the farmers and the farmers should also be well guided on best method to utilize the loan scheme to their benefit. This corroborates the assertion of Ekong (2010) who asserted that when production credit are made available to the rural farmers, the farmers must have easy access to it and should be guided in the use of investment credit in order to expand and improve their production.

Table 1: Mean distribution of respondents by social organisation of labour and capital in agriculture in the colonial and post-colonial periods

\begin{tabular}{|c|c|c|c|c|c|}
\hline & \multicolumn{2}{|c|}{ Colonial } & \multicolumn{2}{|c|}{ Post- Colonial } & \multirow[b]{2}{*}{ t-value } \\
\hline & Mean & $\begin{array}{l}\text { Std. } \\
\text { Deviation }\end{array}$ & Mean & $\begin{array}{l}\text { Std. } \\
\text { Deviation }\end{array}$ & \\
\hline \multicolumn{6}{|l|}{ Labour } \\
\hline Hired labour & 0.37 & 0.881 & 2.46 & 1.047 & $-2.96^{\star}$ \\
\hline Both family and hired labour & 0.45 & 1.019 & $2.40^{* *}$ & 1.100 & -1.47 \\
\hline Family labour & $2.22^{\star \star}$ & 1.085 & 0.44 & 0.990 & 0.23 \\
\hline Communal cooperation & $2.50^{\star \star}$ & 0.650 & 1.51 & 0.549 & $16.69^{\star}$ \\
\hline $\begin{array}{l}\text { Exchange labour } \\
\text { Capital }\end{array}$ & $2.64^{* *}$ & 0.603 & 1.93 & 0.795 & $12.71^{*}$ \\
\hline Reinvestment of proceeds & $2.23^{\star *}$ & 0.727 & $2.45^{\star *}$ & 0.623 & $-4.06^{\star}$ \\
\hline Donations from well wishes & $2.04^{\star *}$ & 0.797 & $2.06^{* *}$ & 0.656 & -0.22 \\
\hline Bank loans & 1.02 & 0.352 & 1.53 & 0.719 & $-11.33^{*}$ \\
\hline $\begin{array}{l}\text { Credit from agric. dev. Ioan } \\
\text { scheme }\end{array}$ & 1.58 & 0.746 & 1.88 & 0.654 & $-5.28^{*}$ \\
\hline Local bam & 1.93 & 0.935 & $2.31^{* *}$ & 0.743 & $-5.62^{*}$ \\
\hline
\end{tabular}




\section{Intra-household decision on agricultural operation among the Tiv}

Various farm decisions were taken by different household members in the colonial and post-colonial periods. Specifically, in the colonial period the husband took such farm decisions as when to cultivate (99\%), where to cultivate $(97.8 \%)$, what type of crop to cultivate $(95.9 \%)$, what to sell when need be $(90.8 \%)$ among others. The wife on the other hand took such decision as ;type of processing method to be used $(78.7 \%)$; which form to process the produce $(74 \%)$ and who does the selling of the produce when need be $(71.4 \%)$ among others.

Jointly, the husband/wife took such decision as measures to resort to incase of food insecurity signals (57.8\%) and measures to ensure food security all year round $(56.8 \%$ ) (Table 2$)$. By the post-colonial period however, the husband alone still took such decisions as: where to cultivate (84.8\%), what type of crop to cultivate $(84.8 \%)$, what to sell when need be $(81.6 \%)$, when to sell $(81.6 \%)$ and when to cultivate (83.5\%). The percentage change analysis shows reduction in none of the decisions of husband except for decisions on "which form to process the produce" $(736.6 \%$ change) and type of processing method to be used ( $1336 \%$ change).

Jointly, the husband/wife still took such decision as how to ensure food security all year round $(80 \%)$, measures to resort to in case of food insecurity signals $(78.4 \%)$, in addition to such other decisions like: who does the selling $(69.2 \%)$, who rears which specie of animal (cow/goat/chicken) (62.9\%) which form to process crops (61.6\%), type of processing method to be used (60.6\%) among others. Percentage change analysis further affirms increased joint decisions in all agricultural issues by women except for what species of livestock to rear (100\% change), how to ensure food security all year round( $215.4 \%$ change) and measures to resort to in case of food insecurity (92.3\% change).

Comparatively, though the women alone did not take major decisions on many farm activities, in the post-colonial period, there was increased involvement of women in joint decision making in all agricultural activities. Remarkable change observed was that in the colonial period, decisions on agricultural activities was based on the roles and control of the activities by the different household members as observed by Bohannan and Bohannan (1968), Burfisher and Horenstein (1985) and Ityavyar (1992) that most decisions on the operation and disposal of farm produce was done on the basis of the role, control and preserve of either men or women. However by the post-colonial period, irrespective of roles, control and preserve of the activities / operations, there was joint decision of the wife and husband in all agricultural activities. The era of when the women alone controlled and took major decisions in all food related issues while the men alone took major decisions in cash crop related issues is over. This result indicates that the effort of the two periods for women 
integration into development has impact on the status of women in development.

The implication of this finding is that development efforts in agriculture in the study area should target both men and women since they are jointly involved in all agricultural activities and even take most decisions jointly.

\section{Table 2: Intra-household decision on agricultural operation in colonial and post-colonial periods}

\begin{tabular}{|c|c|c|c|c|c|c|c|c|}
\hline & Husband & Wife & $\begin{array}{l}\text { Both } \\
\text { husband } \\
\text { and wife }\end{array}$ & Children & Husband & Wife & $\begin{array}{l}\text { Both } \\
\text { husband } \\
\text { and wife }\end{array}$ & Children \\
\hline Where to cultivate & 97.8 & 1.9 & 0.3 & 0 & $\begin{array}{l}84.8 \\
(-13.3)\end{array}$ & $\begin{array}{l}0.6 \\
(-68.4)\end{array}$ & $\begin{array}{l}14.6 \\
(4766.7)\end{array}$ & 0 \\
\hline When to cultivate & 99.0 & 0.6 & 0.3 & 0 & $\begin{array}{l}83.5 \\
(-15.7)\end{array}$ & 0.6 & $\begin{array}{l}15.9 \\
(5200)\end{array}$ & 0 \\
\hline $\begin{array}{l}\text { What type of crop } \\
\text { to cultivate }\end{array}$ & 95.9 & 0.6 & 3.5 & 0 & $\begin{array}{l}84.8 \\
(-11.6\end{array}$ & 0.6 & $\begin{array}{l}14.6 \\
(317.4)\end{array}$ & 0 \\
\hline What to sell & 90.8 & 5.7 & 3.5 & 0 & $\begin{array}{l}81.6 \\
(-10.1)\end{array}$ & $\begin{array}{l}1.9 \\
(-66.7)\end{array}$ & $\begin{array}{l}16.5 \\
(371.4)\end{array}$ & 0 \\
\hline When to sell & 89.5 & 7.0 & 3.5 & 0 & $\begin{array}{l}81.6 \\
(-8.8)\end{array}$ & $\begin{array}{l}1.9 \\
(-72.9)\end{array}$ & $\begin{array}{l}16.5 \\
(371.4)\end{array}$ & 0 \\
\hline $\begin{array}{l}\text { Who does the } \\
\text { selling }\end{array}$ & 9.5 & 71.4 & 19.0 & 0 & $\begin{array}{l}4.8 \\
(-49.5) \\
\end{array}$ & $\begin{array}{l}26.0 \\
(-63.6)\end{array}$ & $\begin{array}{l}69.2 \\
(264.2) \\
\end{array}$ & 0 \\
\hline $\begin{array}{l}\text { Who keeps the } \\
\text { proceeds from sale }\end{array}$ & 85.7 & 7.0 & 7.3 & 0 & $\begin{array}{l}38.4 \\
(-55.2)\end{array}$ & $\begin{array}{l}4.4 \\
(-37.1)\end{array}$ & $\begin{array}{l}57.1 \\
(682.2)\end{array}$ & 0 \\
\hline $\begin{array}{l}\text { What proceeds } \\
\text { from sale are spent } \\
\text { on }\end{array}$ & 89.8 & 2.5 & 7.0 & 0.6 & $\begin{array}{l}39.7 \\
(-55.8)\end{array}$ & 2.5 & $\begin{array}{l}57.8 \\
(725.7)\end{array}$ & $\begin{array}{l}0 \\
(-100)\end{array}$ \\
\hline $\begin{array}{l}\text { What specie of } \\
\text { livestock to rear }\end{array}$ & 82.5 & 1.6 & 15.2 & 0.6 & $\begin{array}{l}41.0 \\
(-50.3)\end{array}$ & $\begin{array}{l}3.2 \\
(100.0)\end{array}$ & $\begin{array}{l}55.9 \\
(267.8)\end{array}$ & $\begin{array}{l}0 \\
(-100)\end{array}$ \\
\hline $\begin{array}{l}\text { Who rears which } \\
\text { specie } \\
\text { (cow/goat/chicken) }\end{array}$ & 77.5 & 2.5 & 19.4 & 0.6 & $\begin{array}{l}34.0 \\
(-56.1)\end{array}$ & 2.5 & $\begin{array}{l}62.9 \\
(224.2)\end{array}$ & 0.6 \\
\hline $\begin{array}{l}\text { Which form to } \\
\text { process the } \\
\text { produce }\end{array}$ & 4.1 & 74 & 20.6 & 1.3 & $\begin{array}{l}34.3 \\
(736.6)\end{array}$ & $\begin{array}{l}4.1 \\
(-94.5)\end{array}$ & $\begin{array}{l}61.6 \\
(199.0)\end{array}$ & $\begin{array}{l}0 \\
(-100)\end{array}$ \\
\hline $\begin{array}{l}\text { Type of processing } \\
\text { method to be used }\end{array}$ & 2.5 & 78.7 & 17.5 & 1.3 & $\begin{array}{l}35.9 \\
(1336)\end{array}$ & $\begin{array}{l}3.5 \\
(-95.6)\end{array}$ & $\begin{array}{l}60.6 \\
246.3)\end{array}$ & $\begin{array}{l}0 \\
(-100)\end{array}$ \\
\hline $\begin{array}{l}\text { How to ensure food } \\
\text { security all year } \\
\text { round }\end{array}$ & 41.9 & 1.3 & 56.8 & 0 & $\begin{array}{l}15.9 \\
(-62.1)\end{array}$ & $\begin{array}{l}4.1 \\
(215.4)\end{array}$ & $\begin{array}{l}80.0 \\
(40.8)\end{array}$ & 0 \\
\hline $\begin{array}{l}\text { Measures to resort } \\
\text { to in case of food } \\
\text { insecurity }\end{array}$ & 41.0 & 1.3 & 57.8 & 0 & $\begin{array}{l}19.0 \\
(-53.7)\end{array}$ & $\begin{array}{l}2.5 \\
(92.3)\end{array}$ & $\begin{array}{l}78.4 \\
(35.6)\end{array}$ & 0 \\
\hline
\end{tabular}

Percentage change in parenthesis Field Survey, 2012

\section{Socio-cultural Practices in Relation to Agriculture among the Tiv}

Table 3 shows that in the colonial period the respondents strongly believed that retaining the Tiv practices would result in improved farm outputs $(M=3.00)$, consulting veterinary agent believing that livestock do better with veterinary attention $(M=2.68)$, as well as encouraging common residence and kinship ties with the belief that it contributes to labor needs $(M=2.63)$. The farmers were also involved in certain practices which such as: Crop failure correction by 
improved inputs $(M=2.58)$ and believing that family head leadership ensures stability/ availability of farm produce $(M=2.84)$, poor performance of livestock is due to witches $(M=2.20)$, crop failures were due to witches $(M=2.15)$ and magic (Akombo) improves farms ( $\mathrm{M}=2.05)$.

By post-colonial period, more respondents still sustained the practice that crop failures could be corrected by improved inputs $(M=3.51)$ and livestock do better with veterinary attention $(\mathrm{M}=3.46)$; while less respondents strongly practiced and believed that retained Tiv traditional practices could result in improved farm output $(M=2.51)$, family head leadership ensures stability/ availability of farm produce $(M=2.23)$ and common residence and kinship ties contribute to labor needs $(M=2.12)$. Such other socio-cultural beliefs like crop failures were due to witches, poor performance of crops and livestock was due to witches, magic (akombo) practice improve farm yields and fear of witchcraft curtails social vices were disagreed upon in the post-colonial period.

Remarkable change observed was that some practices that were culturally and traditionally believed during colonial period were disbelieved by post-colonial period, while some socio-cultural and traditional practices that were still strongly believed while less people as compared to the colonial period still believed it. This may be due to increased awareness brought about by western influence Madeley (2002). The fact that some traditional practices were still strongly believed by post-colonial period could be due to the fact that complete believe in a course cannot be achieved in any innovation or technology diffusion. Agbamu (2005) affirmed this with this state that not every person will normally accept or believe an innovation/ technology at the end of diffusion process, since some may be uninterested and not convinced about the benefits of the innovation due to a general characteristic of farmers which is tradition bound.

\section{Table 3: Socio- cultural and traditional practices in relation to agriculture} in the colonial and post-colonial periods

\begin{tabular}{|c|c|c|c|c|}
\hline \multirow[b]{2}{*}{ Socio-cultural Practices } & \multicolumn{2}{|c|}{ Colonial } & \multicolumn{2}{|c|}{ Post- Colonial } \\
\hline & Mean & $\begin{array}{l}\text { Std. } \\
\text { Deviation }\end{array}$ & Mean & Std. Deviation \\
\hline $\begin{array}{l}\text { Retaining the Tiv practices would result in } \\
\text { improved farm outputs }\end{array}$ & $3.00^{*}$ & 0.93 & $2.51^{*}$ & 0.93 \\
\hline Crop failure correction by improved inputs & $2.58^{*}$ & 0.86 & $3.51^{*}$ & 0.78 \\
\hline Livestock better with veterinary attention & $2.68^{*}$ & 0.82 & $3.46^{*}$ & 0.78 \\
\hline $\begin{array}{l}\text { Family head ensures stability/availability of } \\
\text { farm produce }\end{array}$ & $2.84^{*}$ & 0.91 & $2.23^{*}$ & 0.86 \\
\hline $\begin{array}{l}\text { Common residence and kinship ties } \\
\text { contributes to labor } \\
\text { needs }\end{array}$ & $2.63^{*}$ & 0.94 & $2.12^{*}$ & 0.78 \\
\hline
\end{tabular}




\section{Conclusion}

There are differences among the Tiv farming households between the periods before and after the independence both at household levels and farming decision levels. This is so as several changes were observed among the Tiv household such as their labours in communal cooperation while capital, bank loans as well as local bam also changed. Also jointly, the husband and wife took such decision as measures to resort to in case of food insecurity signals and measures to ensure food security all year round. Also remarkable change observed was that some practices that were culturally and traditionally strongly believed during colonial period were disbelieved by post-colonial period, while some socio-cultural and traditional practices that were still strongly believed were done by less people as compared to the colonial period. Therefore, Nigeria's independence and government interventions have made significant changes/ impact on the Tiv household as a whole as expected.

\section{Recommendation}

Based on the findings of this study, the study recommends that agricultural extension agencies should target both male and female with home economics related technologies which have being solely for the women in with the subcomponent of these agencies, this is because men are now also involved in the household activities which had been known as female roles.

\section{References}

Agbamu, J.U. (2005). Problems and prospects of agricultural extension in developing countries. In: Adedoyin, F.S. (Ed.), Agricultural extension in Nigeria. Agricultural Extension Society of Nigeria, Illorin, pp. 156-169.

Bohannan, p. and Bohannan, L. (1968). Tiv Economy. North Western University Press, Evanston.

Burfisher, M.E. and Horenstein, N.R. (1985). Sex Roles in the Nigerian Tiv Farm Household. Kumarian Press Hartford.

Ekong E. Ekong (2010). Rural Sociology. Third Edition. Dove educational publishers Uyo, Nigeria.

Idyorough, A.E. (2002). Sociological analysis of Social Change in Contemporary Africa. Deka Publications Jos, Jos, Nigeria.

Ityavyar, D.A. (1992). The Changing Socio-economic Role of Tiv Women. Jos University Press Ltd. Jos, Plateau State, Nigeria.

Ivande P.D. (2014). Assess Social and Technological Change in Agriculture among the Tiv, in Nigeria, Ph. D. Thesis submitted to the Department of Agricultural Extension, University of Nigeria. 
Jibowo, A.A. (2005). History of agricultural extension in Nigeria. In: Adedoyin, S.F. (ed.) Agricultural Extension in Nigeria AESON, Ilorin, Nigeria, pp1 15.

Macionis, J.J. and Plummer, K. (2005). Sociology. A Global Introduction; Pearson Education Limited,Edinburgh Gate Hadow England.

Madeley, John (2002). Food for All: The Need for a New Agriculture. Zed book London and NewYork.

Nworgu, F.E (2006). Prospects and pitfalls of Agricultural production in Nigeria. Blessed publication, Ibadan, Nigeria. 